\title{
ANALYTICAL STUDY ON PROVISION OF PUBLIC TOILETS IN LAHORE CITY
}

\author{
Aisha Khan* \\ Muhammad Usman Bajwa** \\ Muhammad Nadeem**** \\ Dr. Gulam Abbas Anjum****
}

\begin{abstract}
Provision of public toilets is not merely a matter of utilizing land, but it is an essential component of design and planning. Inadequate provision of accessible public toilets in the city of Lahore in Pakistan, is not only affecting the quality of the city but is also discomforting its residents. To examine the current status of the public toilets and the major causes of open defecation, a survey of four hundred respondents in different public places of Lahore city was conducted, along with a review of various polices in place with regards to public toilet provision. Principal Component Analysis (PCA) established a comprehensive set of features responsible for achieving an effective solution to provision of public toilets, which ranged from accessibility, to availability, cleanliness, maintenance and safety. The paper reveals that the availability and cleanliness of public toilets should be ensured at potential urban spaces, as that can contribute to healthy and accessible environment for citizens and make cities sustainable and livable.
\end{abstract}

Keywords: Public Toilets, Lahore, Principal component analysis

\section{INTRODUCTION}

Access to appropriate sanitation facilities is an essential requirement and right of human beings. Since the year 2000 , around 1.4 billion people gained access to elementary sanitation facilities, which includes flush lavatories or latrine.
Approximately 2.3 billion persons across the globe lack basic sanitation facilities, along with eight hndred and ninety two million people practicing open defecation (UNICEF and WHO, 2017). Provision of adequate sanitary facilities is the most effective technique for prevention and spreading of diseases. In 2017 the strategic development goals (SDGs) monitored the percentage of people who had access to services of washing hands with water and soap. Around fifty percent of the population of the world in the countryside and eighteen percent in the urban areas lacked sanitation services. Deprived sanitation systems around the world have increased frequency of ailments and pollution in the atmosphere (UNICEF and WHO, 2017). Deprived sanitation system causes death of one and half million children annually (Prüss-Üstün, 2008a). Excreta and solid waste contribute towards unhealthy and polluted environments.

Provision of public toilets at public places of metropolitan cities and towns demands some prerequisites, i.e. water connections, land, electricity, supplementary fixtures, and willingness of managing authorities to look after these facilities. Currently human waste of around two billion people in urban settlements and towns is lacking proper treatment and management before disposal, ultimately waste from cities is disposed in water bodies without primary treatment (Arbogast, et. al., 2015).

In the South Asian region nearly nine hundred fifty three million people do not have access to adequate sanitation and Pakistan ranks amongst those ten nations where there

\footnotetext{
* $\quad$ Aisha Khan, MS Student, Department of Urban Planning, University of Engineering and Technology, Lahore.

Email Correspondance: aishakhan36@gmail.com

** Muhammad Usman Bajwa, MS Student, Department of Urban Planning, University of Engineering and Technology, Lahore.

Email Correspondance: usmanbajwa945@gmail.com

*** Muhammad Nadeem. Assistant Manger In Granna.Com. Lahore.

Email Correspondance: nadeem3910@gmail.com **** $\quad$ Dr. Gulam Abbas (Late), Dean of Architecture and Urban Planning, Department of Urban Planning, University of Engineering and Technology,
Lahore.
} 
is a dire need of improved public toilets facilities (Khan, 2017). The greater proportion of female population in Pakistan is facing agitation, sickness and pestering, as there is a no room for female public toilets at public places. Indeed, Pakistani cities do not have readily available database, documentation and public toilet maps to facilitate urban residents, regarding existing provisioning of public toilets. In Lahore there are twelve public toilets sites operational under the administration of Metropolitan Corporation Lahore (MCL) and twenty seven public toilets sites along ShahdraGajjumata Metro Bus Route. The condition of public toilets of MCL lack proper cleanliness and maintenance. The prevailing condition of public toilets in Lahore and other cities is alarming for development authorities and public representatives in legislation assemblies. The municipalities, planning agencies and urban development specialists should take this issue on board and devise a planning framework for provision of public toilets.

\section{A GLANCE AT HISTORY}

The history of public and private toilets has its roots in ancient civilization of Harappa and Mohenjo-Daro, where every housing unit had its private toilet and well-connected drain to dispose human excreta. Excavations of Egyptian civilization have exposed that they had indoor cesspool toilets in elite class houses, and toilets in temples and other outdoor toilets for the public (Antoniou et. al., 2016). Roman Civilization was famous for their thermae (public baths) and this facility was publicly available in entire Rome. Most of the cities had public bath complexes which were grounds for social gatherings as well (Evans, 2003). Roman public baths had access to water from streams, rivers and aqueducts and $\log$ fire was used for heating water. European cities had advanced public toilet systems during the middle ages. Fortified towns and palaces had common places for bathing. Toilets were also integral components of all religious buildings of the Ottoman Empire. During the Arabs conquests, they conveyed new ethics and codes on hygienic issues, and introduced a structure of public baths, drainage, sewerage and plumbing system. Public toilets were recognized as an essential component of urban houses in the Islamic Empire of Al-Andalus (Antoniou, et. al., and 2016).

\section{MAKING SUSTAINABLE CITIES}

Adequate provision of public toilets at public places endorse the right to participate in social and cultural activities (Bichard and Knight, 2011). Responsive and inclusive public places are major sponsors for quality and healthy life, which supports the agenda of sustainable cities and communities.
Public toilets are integral component for developing sustainable, inclusive and responsive human settlements in the global village. The agenda of '24-Hour City' necessitate authorities to provide supplements like streetlights, urban public transport, security and public toilets for the formulation of the backdrop of a twenty four hour city economy (Greed, 2004). Improved sanitation along with hygiene and clean drinking water are necessary to have a healthy life and socioeconomic development (Mara, et. al., 2010).

Furthermore, consistent interventions in these three basic components of health can considerably combat morbidity and health issues. Past studies shows that adequate sanitation can encounter diarrheal diseases from thirty two to thirty seven percent. Improved sanitation facilities are pivotal to attain substantial goals of poverty alleviation and economic development, because it imparts social development and a healthy environment for the masses (Surya, et. al., 2017). Provision of adequate public toilets not only allows citizens to participate in the city's activities, but also enhances their living standard, which ultimately leads towards sustainable development. It has been observed that many residents, like elders, disabled and women travel occasionally and they often avoid long trips as lack of availability of public toilets discourages them from doing so.

\section{DESIGN OF RESTROOMS}

The design layout for the restrooms in the literature mostly emphasizes on seven principles. Firstly, the provided facility should be used by everybody, it must be flexible, decent and simple to use, tolerant to exploitation, convenient as well as practical in terms of size and place (Sawadsri, 2003). Presence of mirrors in restrooms can enhance security. Some of the accessories to be considered are toilet fixtures, ceilings, door handles and openers, flush, taps, soap, dispensers, hand dryers, paper towels, toilet seats and hot water. Advertisement placed on restroom walls can help offset the cost of its operation and maintenance. Adequately ventilated restrooms can considerably reduce the sense that a restroom is dirty. Management process should include risk assessment, access, security and graffiti management. Sustainable design can include half-flush choice, optimal use of natural lighting and aeration, a minimized lifespan carbon footprint and usage of high value of recyclable materials.

\section{LEGAL FRAMEWORK IN PAKISTAN}

According to UNICEF 2015 report, over forty million Pakistanis do not have access to adequate toilet facility, which compel the masses to defecate openly, which results 
Table 1: Documentation of Different Types of Public Toilets

\begin{tabular}{|c|c|}
\hline A STUDY OF TYPES OF PUBLIC TOILETS & \\
\hline Flush Toilets & $\begin{array}{l}\text { A flush toilet comprises of a ceramic container which is } \\
\text { connected to a up-side tank which rapidly supplies water to } \\
\text { and from the drainage pipe that immediately removes the } \\
\text { effluent. When the toilet is used by the user, manure flows } \\
\text { into the septic tank which is associated with a sewage } \\
\text { treatment plant. }\end{array}$ \\
\hline Squat Toilets & $\begin{array}{l}\text { In 1976, squat toilets were mainly used but now the trend } \\
\text { has changed and public toilets are moving from squat toilets } \\
\text { to sitting toilets. A squat toilet is also known as "squatting } \\
\text { toilet" and sometimes "natural position toilet". They focus } \\
\text { on the position of squatting rather than sitting, which means } \\
\text { the user must place one foot on each side equally in the } \\
\text { direction of the toilet drain hole. This kind of toilet is } \\
\text { commonly used in Asian, African and European countries. } \\
\text { In the Muslim countries, according to Islamic toilet practice, } \\
\text { squat toilets are recommended. }\end{array}$ \\
\hline Pit Latrine & $\begin{array}{l}\text { A pit latrine is a dry lavatory system which accumulates } \\
\text { human excreta in a ditch or trench that ranges from a decent } \\
\text { slit ditch to a more intricate structure, along with seating } \\
\text { and crouching pans and proper ventilation. These are helpful } \\
\text { in emergency circumstances. In developed nations pit latrine } \\
\text { are used in camps and wilderness zones, however they are } \\
\text { also ordinarily used in country and peri-urban areas of many } \\
\text { of the emerging nations. }\end{array}$ \\
\hline Vault Toilets & $\begin{array}{l}\text { They are non-flush toilets encompassing sealed containers } \\
\text { placed in the soil that receives the excreta which remains } \\
\text { in the ground unless it is removed by pumping. A concept } \\
\text { of vault toilet is extracted from a pit lavatory (explained } \\
\text { above). The waste gathers in the vault, does not absorb in } \\
\text { the soil, and acts similarly as a septic tank. }\end{array}$ \\
\hline Urine Diversion Toilets & $\begin{array}{l}\text { These toilets comprise of two sections, both use water for } \\
\text { flushing. These toilets are named as diversion toilets because } \\
\text { its excreta is used for composting or as a biofuel. Astronauts } \\
\text { also use this type of toilet to recover portable water in space. }\end{array}$ \\
\hline Portable Toilets & $\begin{array}{l}\text { These toilets are used in construction sites, in film recording } \\
\text { sites, as well as in outdoor gatherings, where few facilities } \\
\text { are available. They are classically self-contained blocks } \\
\text { which are easily movable portable lavatories and are usually } \\
\text { unisex solitary unit of which privacy is ensured by a lock } \\
\text { on the door of toilet. They are typically light in weight and } \\
\text { can be transferred, loaded and unloaded by a truck. }\end{array}$ \\
\hline Chemical Toilets & $\begin{array}{l}\text { Toilets that do not need any connection to water supply } \\
\text { are termed as chemical toilets and they are used in various } \\
\text { circumstances, like in trains and airplanes. }\end{array}$ \\
\hline
\end{tabular}


in degradation of the environment. Provision of basic facilities like public toilets has never gained the primacy on legislation benches. This negligence on the part of policy makers leads the country to be on third number in the list of open defecation after Republic of India and Indonesia (UNICEF, 2015). According to statistics of national hygiene report, forty four percent of the population lacks access to working toilets, and more than fifty five percent of women, do not have access to safe and secure sanitation. Greater metropolitan and capital cities of Pakistan like Karachi, Lahore, and Peshawar are lacking adequate provision of clean public toilets.

The situation of public toilets provision and management systems in the country are quite poor, which is very alarming for legislators, policymakers, urban planners and development specialists. It is necessary for them to formulate comprehensive public toilet framework and strategy for all administrative tiers. Present legislation and policy provisions for public toilets are in piecemeal, which does not create room for the formulation of comprehensive and inclusive public toilets planning framework and standards.

\section{Punjab Sanitation Policy, 2015}

Section 7.6 of the policy obliges provincial government departments to collaborate with private sector for the provisioning and management of public toilets. Further more, this section makes it compulsory for concerned authorities to guarantee the provision of communal toilets at public places, particularly at commercial markets, bus terminals, parks, playgrounds and open spaces for elderly, male, female and disabled persons. The sanitation policy has devised an outline for the proper construction and operation as well as supervision of public toilets through built-operate and transfer, by encouraging private sector to finance and design public toilets. Likewise, authorities are liable to ensure public participation in planning, construction and operation phases to endorse the sustainable development agenda.

\section{Section 83 of Punjab Local Government Act, 2013}

The metropolitan and municipal committees and the District Councils of Punjab province are major custodians for provision of communal latrines at public places in their areas of jurisdiction, under Section 83 of the Local Government Act. This act safeguards the civic rights of females, elderly, and disabled people, by expounding that there shall be separate public toilets provision for male, female and disabled people. The act states that local agencies have the responsibility of cleanliness and management of public toilets. Local government bodies are empowered to ensure public toilet provision in public buildings, during building plan approval process.

\section{Punjab Land Use (Classification, Reclassification and Redevelopment) Rules, 2009}

The Rule 51 of the land use rules entitled as 'Preparation of Redevelopment Plan' for a project area, which is reclassified from residential to commercial land use, necessitate development agencies to provide public toilets along with other utility services. These rules simply highlight the provision of public toilets, but do not detail out the distribution, location and management of public toilets.

Thus, it can be concluded that the policies and rules related to provision of public toilets in urban areas are inadequately detailed out and non-comprehensive.

\section{STUDY AREA}

The urban site designated for this study is Lahore. which encompasses maintained infrastructure, well established pedestrian circulation patterns, access to public transportation, strong built heritage, gardens, and many other inner-city facilities. The city is a fusion of individuals with diverse skills, ages, educational backgrounds, which makes it a crowded city. It has been observed that Lahore faces problems with regards to access to public toilets. Inadequate provision of readily accessible and responsive public toilets in the city is not only affecting the quality of city centers, public transport terminals, public parks, bazars, public square and religious buildings, but it also muddling the dignity and comfort of the public.

\section{DATA COLLECTION}

Questions were grouped around comfort, uniqueness, clarity, accessibility and security related to public toilets (Burton, and Mitchell, 2006). The concept being explored was to design inclusive neighborhoods which should be accessible and friendly. Questions related to management of public toilets, adequate cleaning regimes, information for uses, proper maintenance and accessibility of toilets were also asked. The premise was that public toilets are a type of place which need to be utilized for fulfilling private need of citizens. They are considered an essential part of civic life in urban areas and they need to be treated according to their specific requirements. 


\section{Targeted Respondents and Sampling Technique}

Calculated sample size is described below

Population of Lahore District $=11,126,285$ people Population of Metropolitan Corporation Lahore $=3,655,774$ people

\section{By applying Slovin's Equation}

$$
\mathrm{n}=\mathrm{N} /(1+\mathrm{Ne} 2)
$$

Here, " $n$ " represents number of respondents ' $N$ ' denotes "total population" of an area, that is in this case "Lahore region", and "e" is the . For better accuracy confidence interval of $95 \%$ was used.

\section{Computation for the Confidence Level}

$$
\begin{aligned}
\mathrm{e} & =100 \%-95 \%=5 \%=0.05 \\
\mathrm{n} & =3655774 / 1+3655774(0.05) 2 \\
& =3655774 / 9140.435 \\
& =399.95400
\end{aligned}
$$

A calculated sample size of four hundred respondents was used, in which people were questioned regarding their demands, requirements and expectations about inclusiveness and better communal lavatories. Likert scale of 5 attributes was designed, which ranged from "1" Strongly Agree to "5" Strongly Disagree respectively. Throughout the survey, participants were requested to rate the significance level of entries listed under each parameter on a provided Likert scale of range (1 to 5), to recognize the status of each individual parameter in understanding the consumption and usage of a lavatory and its environment.

In Figure 1, public toilets which were researched for this survey are marked. These toilets were observed, photographed and examined by the researchers to gather primary data (Figure 1).

\section{ANALYSIS}

Before starting the analysis of the data, the researchers examined the data thoroughly to settle that which objects at the radical ends of the scale ought to be eradicated by compressing and classifying the collected data. Principal Component Analysis (PCA) technique helped in this regard, as it condensed the dimensions of the data set (collected samples) by establishing new variables, which reduced the original variable's set. Five foremost independent variables were availability, accessibility, cleanliness, maintenance and safety. To find the vital variables and to transmute them into substantial components, PCA was applied on these variables (Table 2).

Pearson correlations method was applied on the response scores to create a correlation matrix. All the responses were demonstrated in the form of rows and columns to show statistical relationship with the correlation scores. Those items which had a correlation score of less than 0.30 were neglected, because 1.00 score specifies that variables have perfect association conferring to each other.

Table 3 shows that the value of Kaiser-Meyer-Olkin of Sampling Adequacy is more than 0.5 with .00 significance, that specifies that PCA is applicable and appropriate to use.

According to Greed, 2006, accessibility to toilets, availability of toilets, quality of staff are the major components that should be used for analysis. Furthermore, attendants must be competent and rewarded fairly. Cleaning supervisors should be the front-line troops in control of diseases and dirt that usually attract hovers, lice, mice, fleas and ticks, which are major cause of dispersing ailment (Hawker et al, 2004). Having public lavatories that are hygienic also supports its appropriate operation and preservation, and the interactive variation of its users. Not ensuring better cleaning of public lavatories results in illness (Greed, 2006). Gender also plays an important part in sanitation facilities, which needs to be considered because of physical variances and privacy issues.

Before determining the rotation of variables, the correlation among the regression factor score 1 and 2 needed to be calculated. The variables were mainly divided into two parts which depended on loading. Table $5 \mathrm{~b}$ indicates that there was no correlation between regression factor score 1 and 2, which clearly suggests to use varimax rotation to determine the variable's loading.

The loading of variables in different components can be seen in (Figure 3).

Figure 3 displays the loading of variables when Varimax rotation was applied and this stage continued untill the researchers got the noteworthy loading of the variables. After some rotations, decisive stage was obtained (Table 6). The aim of providing public toilets is to offer an operative and sustainable facility that may respond to users' desires at a reasonable price, and which may also help to improve environmental settings and sanitary conditions within an area. Table 6 undoubtedly indicates the two components 


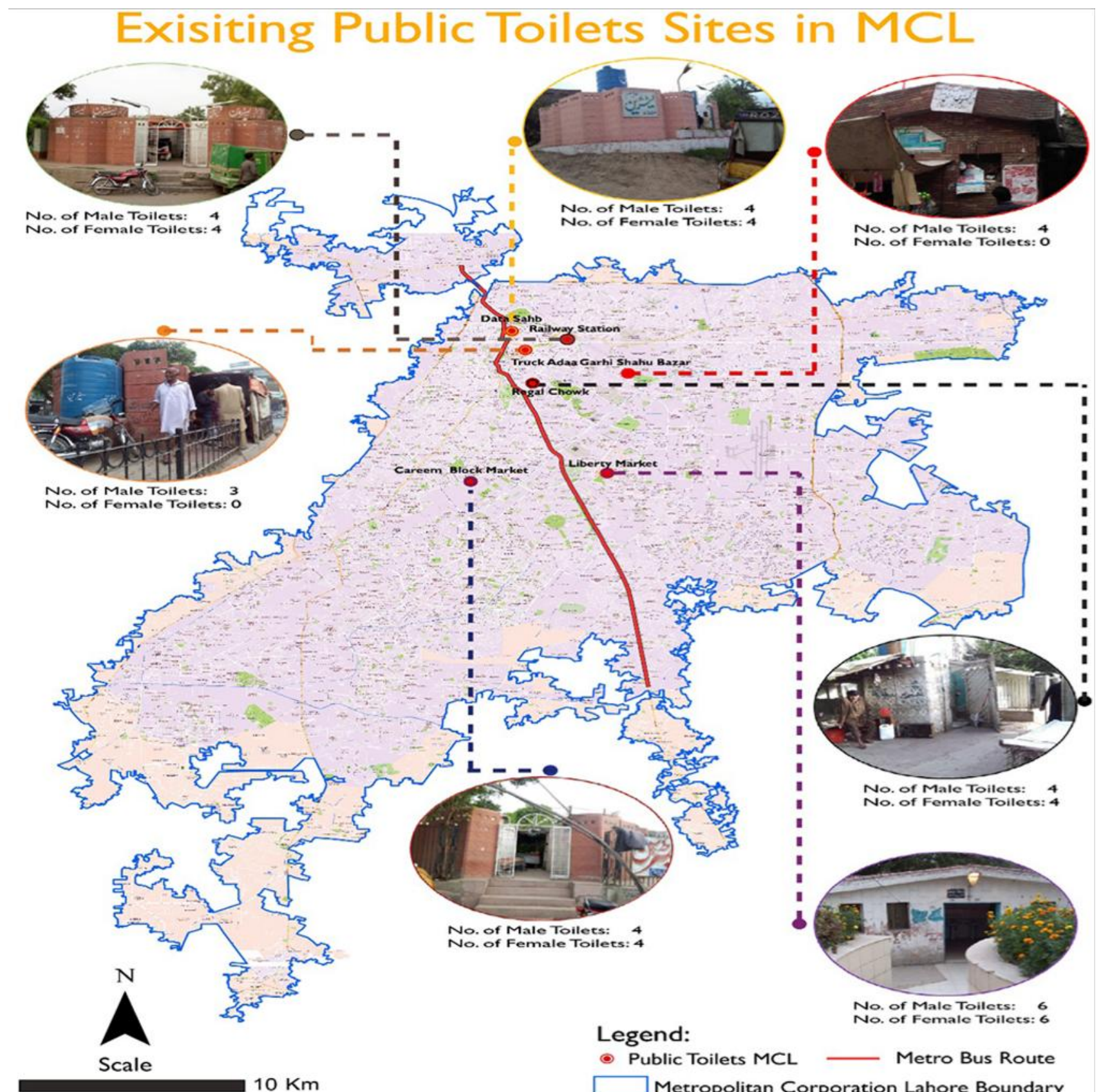

Figure 1: Location of Case Studies of Public Toilets, Lahore. 
with set of variables, in which component 1 comprises of 3 variables, which are availability, accessibility and safety for women in public toilets. Similarly, it has been distinguished that social aspects like instructions for users, training of chars, cleaners and assistants and ethnic variation in social attitude to the toilets are considered central pillars in operation and maintenance of public toilets. Component 2 in Table 6 encompasses two variables, explicitly, cleanliness and maintenance of public toilets, though it has also been proven that cleanliness and maintenance play a vital role in usage of toilets.

\section{Regression Analysis}

By conducting PCA on the variables, it was found that out of five variables, two were significant features.

Table 2: PCA Without Rotation and Correlation Between Selected Variables.

\begin{tabular}{|c|c|c|c|c|c|c|}
\hline & & $\begin{array}{c}\text { Availability of } \\
\text { Toilets }\end{array}$ & $\begin{array}{c}\text { Accessibility to } \\
\text { Toilets }\end{array}$ & $\begin{array}{c}\text { Cleanliness of } \\
\text { Toilets }\end{array}$ & $\begin{array}{c}\text { Maintenance of } \\
\text { Toilets }\end{array}$ & $\begin{array}{c}\text { Safety for Woman } \\
\text { at Toilets }\end{array}$ \\
\hline \multirow{5}{*}{ Correlation } & $\begin{array}{l}\text { Availability of } \\
\text { Public Toilets }\end{array}$ & 1.000 & .494 & .168 & .317 & .504 \\
\hline & $\begin{array}{l}\text { Accessibility to } \\
\text { Public Toilets }\end{array}$ & .494 & 1.000 & .231 & .353 & .594 \\
\hline & $\begin{array}{l}\text { Cleanliness of } \\
\text { Public Toilets }\end{array}$ & .168 & .231 & 1.000 & .553 & .140 \\
\hline & $\begin{array}{c}\text { Maintenance of } \\
\text { Toilets }\end{array}$ & .317 & .353 & .553 & 1.000 & .424 \\
\hline & $\begin{array}{c}\text { Safety for Woman } \\
\text { at Toilets }\end{array}$ & .504 & .594 & .140 & .424 & 1.000 \\
\hline
\end{tabular}

Source: Developed by Researchers

Table 3: PCA Significance of PCA and Communalities Extraction Matrix

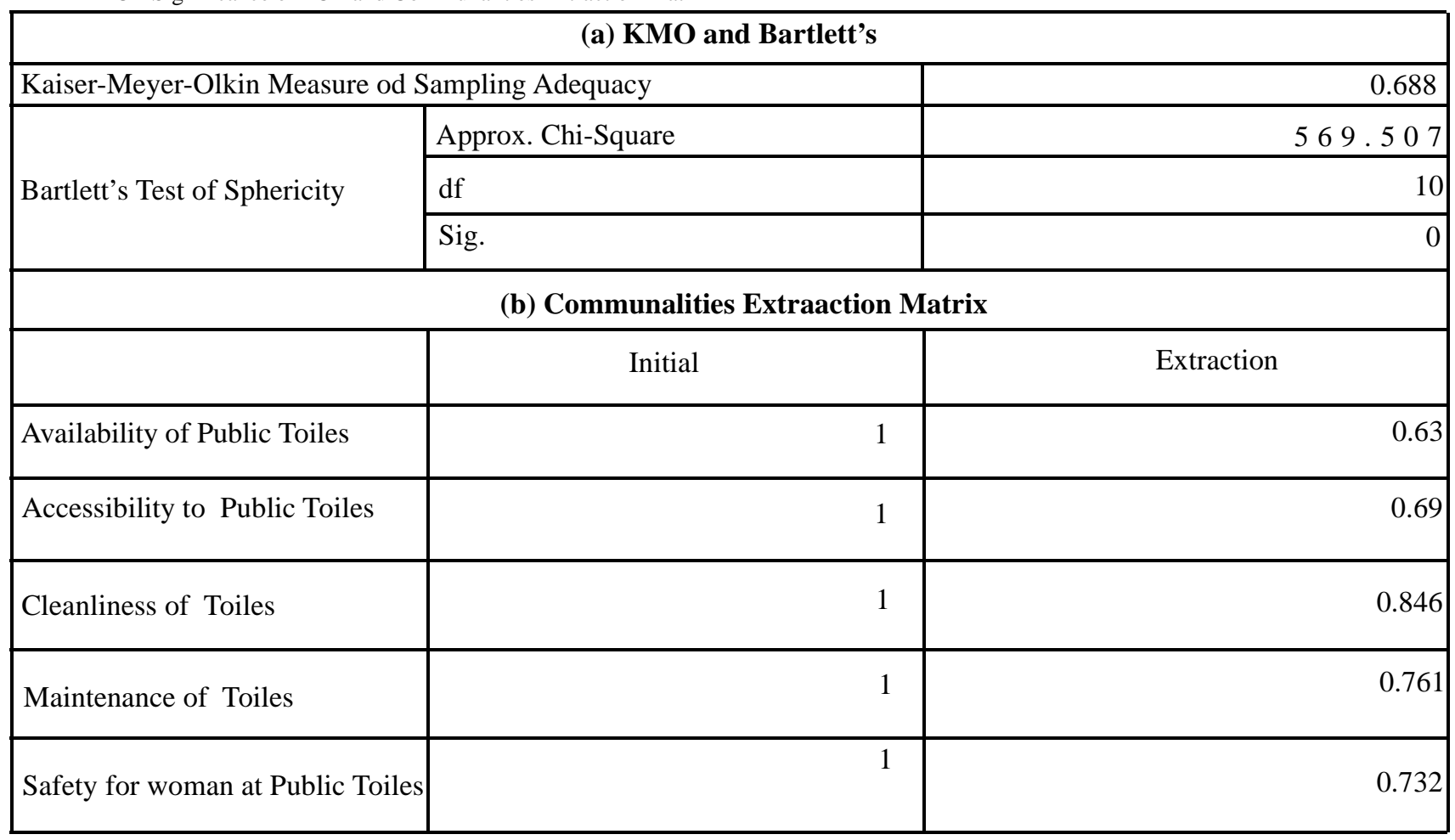


Table 4: Eigenvalues and Variance of the Componets

\begin{tabular}{|c|c|c|c|c|c|c|}
\hline \multicolumn{7}{|c|}{ Total Variance Explained } \\
\hline \multirow{2}{*}{ Component } & \multicolumn{3}{|c|}{ Initial Eigenvalues } & \multicolumn{3}{|c|}{ Extraction Sums of Squared Loadings } \\
\hline & Total & $\%$ of Varisnce & Cumulative $\%$ & Total & $\%$ of Varisnce & Cumulative $\%$ \\
\hline 1 & 2.540 & 50.793 & 50.793 & 2.540 & 50.793 & 50.793 \\
\hline 2 & 1.119 & 22.376 & 73.169 & 1.119 & 22.376 & 73.169 \\
\hline 3 & .537 & 10.745 & 83.914 & & & \\
\hline 4 & .479 & 9.585 & 93.499 & & & \\
\hline 5 & .325 & 6.501 & 100.000 & & & \\
\hline
\end{tabular}

Table 4 specifies that only 2 components have eigenvalue more than 1 which embodies $73 \%$ of the total variance whereas, component 1 has $50.7 \%$ and component 2 has $22.3 \%$. (Figure 2).

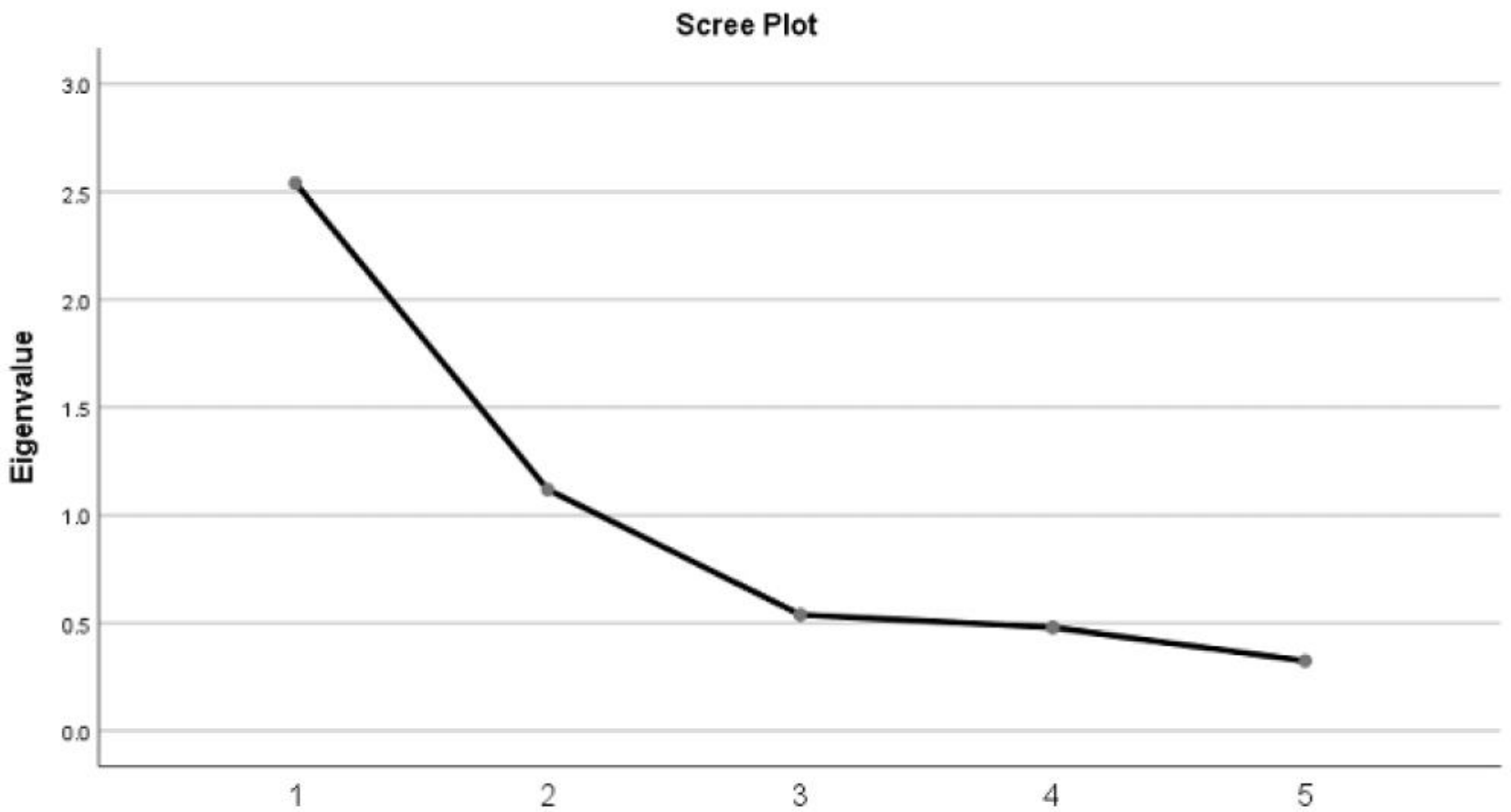

Figure 2: Scree Plot

Component Number

The scree plot endorses that the stroke is steeper among components 1 and 2 (Figure 2). 
Table 5: Loading of Variables and Correlations Between Regression Factors

\begin{tabular}{|l|r|r|}
\hline \multicolumn{2}{|c|}{ (a) Component Matrix } \\
\hline & \multicolumn{2}{|c|}{ Component } \\
\cline { 2 - 4 } & \multicolumn{2}{|c|}{2} \\
\hline Safety for woman at Public Toiles & 0.783 & -0.346 \\
\hline Accessibility to Public Toiles & 0.778 & -0.292 \\
\hline Maintenance of PublicToiles & 0.731 & 0.476 \\
\hline Availability of Public Toiles & 0.714 & -0.374 \\
\hline Cleanliness of Public Toiles & 0.528 & 0.753 \\
\hline
\end{tabular}

(b) Correlations Between the Regression Factors

\begin{tabular}{|l|l|r|r|}
\hline \multicolumn{2}{|c|}{} & $\begin{array}{c}\text { REGR Factor Score 1 for } \\
\text { Analysis 1 }\end{array}$ & $\begin{array}{c}\text { REGR Factor Score 2 for } \\
\text { Analysis 1 }\end{array}$ \\
\hline \multirow{4}{*}{$\begin{array}{c}\text { REGR Factor Score 1 for } \\
\text { Analysis 1 }\end{array}$} & Pearson Correlation & 1 & 0 \\
\cline { 2 - 4 } & Sig. (2-tailed) & & 4 \\
\cline { 2 - 4 } & N & 400 & 400 \\
\hline \multirow{3}{*}{$\begin{array}{c}\text { REGR Factor Score 2 for } \\
\text { Analysis 1 }\end{array}$} & Pearson Correlation & 0 & 1 \\
\cline { 2 - 4 } & Sig. (2-tailed) & 1 & 400 \\
\cline { 2 - 5 } & N & 400 & \\
\hline
\end{tabular}

Furthermore, before commencing towards regression, it was essential to check either the variables were collinear or not. Regression analysis attempted to summarize the regression coefficients from the model established by the authors. It also helped to determine the relation between the usage of public toilets and other independent variables (Table 7).

Table 8a shows that $\mathrm{R} 2$ value was significant. The established model defined that the accuracy was of $94 \%$ among variables. Table $8 \mathrm{~b}$ displays that the interrelationship between variables was significant. Table $8 \mathrm{c}$ specifies that the availability of public toilets has more significant relationship with usage of public toilets than cleanliness of public toilets.
The regression equation can be illustrated as:

Where

$$
Y=27.295+291.790(X 1)+77.87(X 2)
$$

$\mathrm{Y}=$ Usage of public toilets;

$\mathrm{X} 1$ = Availability of public toilets; and

$\mathrm{X} 2=$ Cleanliness of public toilets

This model expresses that the usage of public toilets depends on both the availability of public toilets and their cleanliness. 


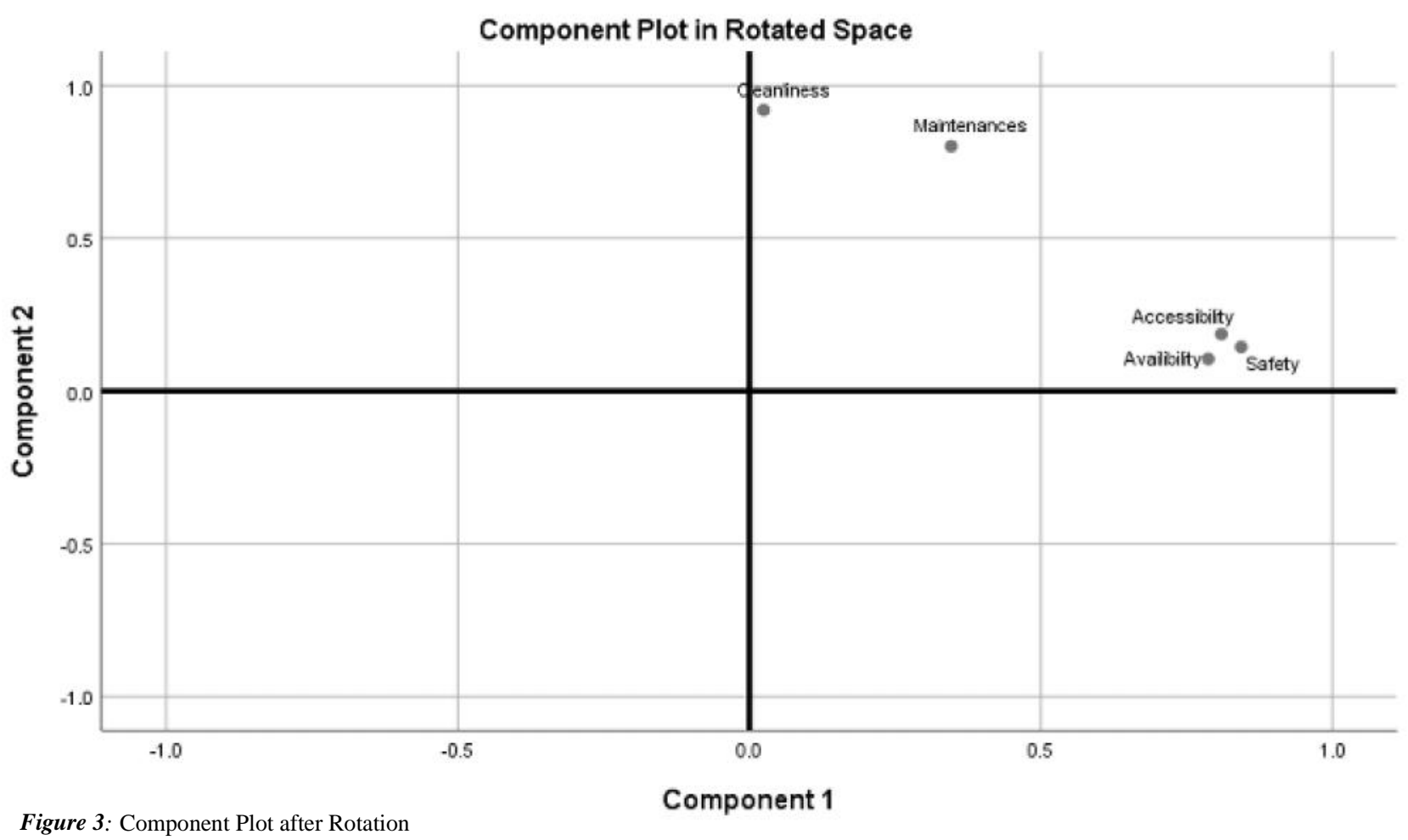

Table 6: Significant Variable and Component Transformation Matrix

\begin{tabular}{|c|c|c|c|}
\hline \multicolumn{4}{|c|}{ (a) Rotated Component Matrix } \\
\hline & & \multicolumn{2}{|c|}{ Component } \\
\hline & & 1 & 2 \\
\hline Safety for woman at Public Toiles & & 0.843 & 0.144 \\
\hline Accessibility to Public Toiles & & 0.809 & 0.186 \\
\hline Maintenance of PublicToiles & & 0.787 & 0.105 \\
\hline Availability of Public Toiles & & 0.024 & 0.919 \\
\hline Safety for woman at Public Toiles & & 0.346 & 0.801 \\
\hline \multicolumn{4}{|c|}{ (b) Component Transformation Matrix } \\
\hline Component & & 1 & 2 \\
\hline & 1 & 0.833 & 0.553 \\
\hline & 2 & -0.553 & 0.833 \\
\hline
\end{tabular}

Source: Developed by Researchers 
The equation can be divided into two representative models to assess influences of the variables separately:

$$
\begin{array}{ll}
Y=27.295+291.790(X 1) & \text { Eq }(1) \\
Y=27.295+77.87(X 2) & \text { Eq }(2)
\end{array}
$$

\section{DISCUSSION AND ANALYSIS}

Adequate public toilets complement functionality, livability, inclusivity, and personalization of the city, where public has confidence on civic facilities when they visit public places. Public toilets facility has significant impact on several domains of life and promotes public ability at shopping areas, at work places, at public parks and entertainment areas.
Furthermore, the inadequate provision of civic facilities like public toilets has devastating impact on people's health. The analysis of this study reveales that most respondents had information regarding sanitation services and disadvantages of defecating in open spaces. But at the same time many of the respondents (male) admitted that they used open places for urinating, because of non-availability of sufficient public toilets. This act has harmful effects on both the environment as well as health of citizens. Inadequate maintenance, and lack of proper cleaning of toilets also causes illness. Consequently, there is a desperate necessity for more public lavatories in crowded cities like Lahore. The research also found that two major factors, namely cleanliness and availability of the public toilets, were the two most significant factors related to usage of public toilets.

\begin{tabular}{|c|c|c|c|c|c|c|c|}
\hline & & $\begin{array}{c}\text { Availability } \\
\text { of } \\
\text { Public Toilets }\end{array}$ & $\begin{array}{c}\text { Accessibility } \\
\text { to } \\
\text { Toilets }\end{array}$ & $\begin{array}{c}\text { Cleanliness } \\
\text { of } \\
\text { Toilets }\end{array}$ & $\begin{array}{c}\text { Maintenance } \\
\text { of } \\
\text { Toilets }\end{array}$ & $\begin{array}{l}\text { Safety for } \\
\text { Woman } \\
\text { at Toilets }\end{array}$ & $\begin{array}{l}\text { Usage of } \\
\text { Public } \\
\text { Toilets }\end{array}$ \\
\hline \multirow{3}{*}{$\begin{array}{l}\text { Availability } \\
\text { of } \\
\text { Public Toilets }\end{array}$} & $\begin{array}{l}\text { Pearson } \\
\text { Correlation }\end{array}$ & 1 & $.494 * *$ & $.168 * *$ & $.317 * *$ & $.504 * *$ & $-.519 * *$ \\
\hline & Sig. (2-tailed) & & .000 & .001 & .000 & .000 & .000 \\
\hline & $\mathrm{N}$ & 400 & 400 & 400 & 400 & 400 & 400 \\
\hline \multirow{3}{*}{$\begin{array}{c}\text { Accessibility } \\
\text { to } \\
\text { Toilets }\end{array}$} & $\begin{array}{l}\text { Pearson } \\
\text { Correlation }\end{array}$ & $.494 * *$ & 1 & $.231 * *$ & $.353 * *$ & $.594 * *$ & $-.476 * *$ \\
\hline & Sig. (2-tailed) & .000 & & .000 & .000 & .000 & .000 \\
\hline & $\mathrm{N}$ & 400 & 400 & 400 & 400 & 400 & 400 \\
\hline \multirow{3}{*}{$\begin{array}{c}\text { Cleanliness } \\
\text { of } \\
\text { Toilets }\end{array}$} & $\begin{array}{l}\text { Pearson } \\
\text { Correlation }\end{array}$ & $.168 * *$ & $.231 * *$ & 1 & $.553 * *$ & $.140 * *$ & $-.131 * *$ \\
\hline & Sig. (2-tailed) & .001 & .000 & & .000 & .000 & .000 \\
\hline & $\mathrm{N}$ & 400 & 400 & 400 & 400 & 400 & 400 \\
\hline \multirow{3}{*}{$\begin{array}{c}\text { Maintenance } \\
\text { of } \\
\text { Toilets }\end{array}$} & $\begin{array}{l}\text { Pearson } \\
\text { Correlation }\end{array}$ & $.317 * *$ & $.353 * *$ & $.553 * *$ & 1 & $.424 * *$ & $-.353 * *$ \\
\hline & Sig. (2-tailed) & .000 & .000 & .000 & & .000 & .000 \\
\hline & $\mathrm{N}$ & 400 & 400 & 400 & 400 & 400 & 400 \\
\hline \multirow{3}{*}{$\begin{array}{l}\text { Safety for } \\
\text { Woman } \\
\text { at Toilets }\end{array}$} & $\begin{array}{l}\text { Pearson } \\
\text { Correlation }\end{array}$ & $.504 * *$ & $.594 * *$ & $.140 * *$ & $.424 * *$ & 1 & $-.551 * *$ \\
\hline & Sig. (2-tailed) & .000 & .000 & .005 & .000 & & .000 \\
\hline & $\mathrm{N}$ & 400 & 400 & 400 & 400 & 400 & 400 \\
\hline \multirow{3}{*}{$\begin{array}{l}\text { Usage of } \\
\text { Public } \\
\text { Toilets }\end{array}$} & $\begin{array}{l}\text { Pearson } \\
\text { Correlation }\end{array}$ & $-.519 * *$ & $-.476 * *$ & $-.131 * *$ & $-.353 * *$ & $-.551 * *$ & 1 \\
\hline & Sig. (2-tailed) & .000 & .000 & .009 & .000 & .000 & \\
\hline & $\mathrm{N}$ & 400 & 400 & 400 & 400 & 400 & 400 \\
\hline
\end{tabular}

Table 7: Five Significant Variables that were Obtained in Two Components Formation 
Table 8a-8c: Inter Relationship Between Variables

\begin{tabular}{|c|c|c|c|c|c|c|}
\hline \multicolumn{7}{|c|}{ (a) Model Summary } \\
\hline Model & $\mathrm{R}$ & $\mathrm{R}^{2}$ & Adjusted $\mathrm{R}^{2}$ & \multicolumn{3}{|c|}{ Std. Error of the Estimate } \\
\hline 1 & $.937^{\mathrm{a}}$ & 0.877 & 0.816 & \multicolumn{3}{|c|}{86.72549} \\
\hline \multicolumn{7}{|c|}{ a. Predictors: (Constant), Cleanliness of Public Toilets, Availability of Public Toilets } \\
\hline \multicolumn{7}{|c|}{ (b) ANOVA ${ }^{\text {a }}$} \\
\hline \multicolumn{2}{|l|}{ Model } & Sum of Squares & $\mathrm{df}$ & Mean Square & $\mathrm{F}$ & Sig. \\
\hline \multirow{3}{*}{1} & Regression & 33.716 & 2 & 16.858 & 73.738 & $.000^{\mathrm{b}}$ \\
\hline & Residual & 90.762 & 397 & 0.229 & & \\
\hline & Total & 124.477 & 399 & & & \\
\hline \multicolumn{7}{|c|}{ a. Dependent Variable: Usage of Public Toilets } \\
\hline \multicolumn{7}{|c|}{ b. Predictors: (Constant), Cleanliness of Public Toilets, Availability of Public Toilets } \\
\hline \multicolumn{7}{|c|}{ (c) Coefficients ${ }^{\text {a }}$} \\
\hline \multirow[t]{2}{*}{ Model } & & \multicolumn{2}{|c|}{ Unstandardized Coefficients } & $\begin{array}{l}\text { Standardized } \\
\text { Coefficients }\end{array}$ & $\mathrm{t}$ & Sig. \\
\hline & & B & Std. Error & Beta & & \\
\hline \multirow{3}{*}{1} & (Constant) & 27.295 & 188.868 & & 0.147 & 0 \\
\hline & $\begin{array}{l}\text { Availability of } \\
\text { Public Toilets }\end{array}$ & 291.79 & 60.067 & 0.887 & 4.864 & 0 \\
\hline & $\begin{array}{l}\text { Cleanliness of } \\
\text { Public Toilets }\end{array}$ & 77.87 & 106.07 & 0.136 & 0.742 & 0.476 \\
\hline
\end{tabular}

The societal and physical roles of public lavatories in cities are indisputable as they are considered as the image of our ethos (Anthony and Dufresne, 2007). The provision of communal toilets is a perilous component of the built-up environment.

In the primary research, the presence of five comprehensive public lavatory features, in a set of correlations, helped achieve an effective solution to provision of public toilet. Each factor was considered individually as well as with its variables concurrently. The model established that the usage of public toilets depends on their availability. Greed (2003) claims, that public toilets are former priority for urban places, which also applies in the city of Lahore. Thus, it is essential to develop city wide strategic policies to resolve complications in public lavatory provision and supervision.

Well organized local administrations must pursue and apply inputs provided by users and hire specialists who are aware of the usage and practice of public toilets. The public must be guaranteed a safer and healthy environment for usage of public toilets. Promoting a philosophy of cleanliness would result in better provision of toilets for everyone (Greed, 2008). In this regard, an inclusive communal toilet provision can improve city life, as it is essential for resilient urban planning, social participation and elimination of pollution and diseases and in achieving sustainable development. 


\section{RECOMMENDATIONS AND WAY FORWARD}

Based on the analysis of the primary data and observation of public toilets that the following interventions are suggerted that can bring fruitful results with respect to provision of public toilets.

1. Development authorities should develop public toilet strategy as supplementary document of integrated master plan of Lahore City, which embodies spatial distribution and hierarchy of public toilets, which are compatible with various land uses (commercial, residential, open spaces) as essential component of development.

2. The government should work in corporation with the private sector, societies and social organizations and should provide policies for improvement in sanitation system, in terms of operational and management arrangements and by means of calculating costs and revenues. The government should also provide incentives to the public groups and stakeholders to participate in this activity. Moreover, to meet costs, a small charge for the public toilets can be considered per user.

3. Development authorities should categorize 'toilet hotspots' in public spaces of Lahore, to construct new public toilets and make action plans for the upgradation and renewal of existing public toilets, in collaboration with Metropolitan Corporation of Lahore.

4. Development authorities, in collaboration with concerned departments, should make citywide documentation of public toilets, using satellite maps and ensuring adequate advertisement of these maps on public places to facilitate visitors. Likewise, it should be ensured that special provisions in design of public toilets are made for the disabled and visually impaired persons, to endorse the agenda of inclusive and sustainable cities.

5. Adequate provision of separate female public toilets, at public places, should be made to endorse the perspective of gendered oriented cities. This can be a major contributory factor in women empowerment and can improve women participation in urban economics.

6. The local authorities should also develop hierarchies of 'toilet magnets', for instance public toilets should be placed at public transport terminals, commercial hubs of the city, public squares, public bazars, near religious buildings, parks and playgrounds.
7. The development authorities should develop and formulate standards for public toilet provision, like British Standard for Public Toilets (BS 6465), which necessitate developers of retail markets and shopping malls to provide one toilet and urinal for male, two women only toilets, and one unisex toilets for special persons for every retail floor area of every one thusand to two thousand square meters.

8. Spatial distribution of public toilets should ensure smooth access to public toilets.

9. A monitoring and evaluation system for adequate provision of public toilet facilities should be developed, including cleanliness, maintenance and compliance with rules and regulations and defined terms and conditions.

10. It should be ensured that all toilet facilities, like sufficient litter baskets, sufficient supply of urinal paper, sanitary discarding baskets in every female lavatory cubicle, adequate supply of liquid soap, paper towels, are in decent working order.

11. Finally, in a society where many people have no idea how to use such a facility, some guidance through appropriate media can be planned and provided.

\section{LIMITATIONS}

This study also has some limitations, such as the samples collected were only from Lahore. Future studies should include samples from different cities of Pakistan, focusing on administrative policies, codes and standards for public toilets and engagement of policy makers in providing public toilets.

\section{DEDICATION}

This research paper is dedicated to our beloved teacher Dr. Prof Gulam Abbas Anjum. We are thankful to him because his efforts made us capable of doing research on such a wide topic. Although he is no longer with us but his efforts throughout his course cannot be emphasized enough. 


\section{REFERENCES}

Antoniou, G. et. al., 2016, "Evolution of Toilet World Wide Through the Millennia", Sustainbility, 8(8): 779.

Arbogast, L.W., Brinson, R.G. and Marino, J.P., 2015, "Mapping Monoclonal Antibody Structure by 2D 13C NMR at Natural Abundance", Analytical Chemistry, 87(7): 3556-3561.

Anthony, K.H., Dufresne, M., 2007, "Potty Parity in Perspective: Gender and Family Issues in Planning and Designing Public Restrooms", Journal of Planning Literature 21: 267-294.

Bichard, J.-A., Knight, G., 2012, "Improving Public Services Through Open Data: Public Toilets", Proceedings of the Institution of Civil Engineers - Municipal Engineer, 165: 157-165.

Burton, E. and Mitchell, L., 2006, "Neighbourhoods for Life: Designing Dementia - Friendly Outdoor Environments", Quality in Ageing and Older Adults, 7(1): 26-33.

Evans, G.W., Wells, N.M. and Moch, A., 2003, “ Housing and Mental Health: A Review of the Evidence and a Methodological and Conceptual Critique”, Journal of Social Issues, 59(3): 475-500.

Greed, C., 2008, “Improving Public Access to Better Quality Toilets: A Strategic Guide,” Gendered Mobilities, 243-256.

Greed, C., 2006, “The Role of the Public Toilet: Pathogen Transmitter or Health Sacilitator?", Building Services Engineering Research and Technology, 27: 127-139.

Greed, C., 2004, “A Code of Practice for Public Toilets in Britain”, World Toilet Summit of The World Toilet Organization, Beijing.

Hawker, J. and Ali, S., 2004, "Ethnic Inqequalities in Campylobacter Infection in Birmingham, UK: Decriptive study of Notified Cases", Joural of Epidemiology and Community, 58(4): 278-279.

Khan, G. F., 2017, "Social Media for Government: A Practial Guide to Understandin”, Implementing , and Managing Soical Media Tools in the Public Sphere, London, Springer.

Mara, D., Lane, J., Scott, B. and Trouba, D., 2010, "Sanitation and Health", PLoS Medicine, 7(11): 113-119.

Pruss - Ustun, A., 2008a, "Safer Water, Better Health: Costs, Benefits and Sustainability of Intervention to Protect and Promote Health", World Health Organization.

Surya, A.V., Vyas, A., Krishna, M. and Abidi, N., 2017, "Identifying Determinants of Toilet Usage by Poor in Urban India", Procedia Computer Science, 122: 634-641.

Unicef, 2015, "Joint Water Supply and Sanitation Programme", World Health Organisation. Unicef and WHO, 2017, "Joint water Supply, Sanitation Monitoring Programme”, World Health Organisation. 